\title{
ANALISIS EFISIENSI TEKNIS PENGGUNAAN FAKTOR-FAKTOR PRODUKSI USAHATANI SEMANGKA DI DESA MAYANGAN KECAMATAN GUMUKMAS KABUPATEN JEMBER
}

\section{[TECHNICAL EFFICIENCY ANALYSIS IN THE USE OF WATERMELONPRODUCTION FACTORSINMAYANGAN VILLAGE GUMUKMAS SUB-DISTRICT JEMBER REGENCY]}

\author{
Luluk Rofiqoh $^{1)}$, Titin Agustina ${ }^{1)}$ dan Rudi Hartadi ${ }^{1)}$ \\ 1) Fakultas Pertanian universitas Jember \\ Email: luluk.rofiqoh16@gmail.com
}

\begin{abstract}
ABSTRAK
Desa Mayangan sudah lama membudidayakan semangka akan tetapi masih terjadi kendala diantaranya tingkat produktivitas yang masih rendah, kapasitas produksi yang menurun, kondisi iklim dan cuaca yang tidak menentu. Tingkat produktivitas yang rendah dapat berhubungan dengan penggunaan faktor produksi serta tingkat efisien petani dalam menggunakan input yang ada. Penelitian ini bertujuan untuk: (1) mengetahui faktor-faktor apa saja yang mempengaruhi tingkat produksi, (2) efisiensi teknis usahatani semangka, (3) faktor-faktor yang mempengaruhi inefisiensi teknis usahatani semangka di Desa Mayangan Kecamatan Gumukmas Kabupaten Jember. Metode dalam penelitian menggunakan data deskriptif dan analitis dengan pengambilan contoh dilakukan dengan cara Proportionate stratified random sampling, sehingga terpilih 50 sampel petani semangka berdasarkan tingkatan luas lahan. Hasil penelitian menunjukkan bahwa: (1) Faktor-faktor yang mempengaruhi produksi semangka di Desa Mayangan adalah luas lahan $\left(\mathrm{X}_{1}\right)$, tenaga kerja $\left(\mathrm{X}_{2}\right)$, pupuk organik $\left(\mathrm{X}_{3}\right)$, pupuk kimia $\left(\mathrm{X}_{4}\right)$, dan bibit $\left(\mathrm{X}_{5}\right)$, sedangkan pestisida cair $\left(\mathrm{X}_{6}\right)$ dan pestisida padat $\left(\mathrm{X}_{7}\right)$ tidak berpengaruh nyata. (2) Tingkat efisiensi teknis petani semangka secara keseluruhan dalam penggunaan faktor produksi semangka di Desa Mayangan dengan rata-rata sebesar 0,68. (3) Faktor-faktor yang mempengaruhi inefisiensi teknis secara parsial dalam usahatani semangka di Desa Mayangan adalah pengalaman petani (tahun) dan dummy keikutsertaan kelompok tani.
\end{abstract}

\begin{abstract}
Mayangan village has cultivated watermelons long time ago, but still there are obstacles such as low productivity levels, declining production capacity, climatic conditions and unpredictable weather. Low productivity levels can be related to the use of production factors and the efficient level of farmers in using existing inputs. This study aims to: (1) know what factors that influence the level of production, (2) the technical efficiency of watermelon farming, (3) the factors that influence the technical inefficiency of watermelon farming in Mayangan village, Gumukmas district, Jember regency. Methods in this research use descriptive, corellations and analytical data with sampling use proportionate stratified random sampling, so selected 50 samples of watermelon farmers based on the level of land area. The results showed that: (1) Factors influencing watermelon production in Mayangan Village are land area (X1), labor (X2), organic fertilizer (X3), chemical fertilizer (X4), and seed (X5). (2) The overall technical efficiency level of watermelon farmers in the use of watermelon production factors in Mayangan Village with an average of 0.68. (3) Factors affecting partial technical inefficiency in watermelon farming in Mayangan Village are farmer's experience (year) and dummy of farmer group participation.
\end{abstract}

Keywords: Efficiency technical, production, watermelon, stochastic frontier.

\section{PENDAHULUAN}

Semangka merupakan salah satu komoditas hortikultura buah yang memiliki kontribusi produksi sebesar 576.178 ton dengan nilai persentase sebesar $2,86 \%$ dan memiliki urutan ke-10 dari 26 jenis komiditas buah yang ada di Indonesia. Rata-rata tingkat konsumsi semangka perkapita sebesar 13,13\% per tahun dan tingkat penyediaan semangka per kapita hanya mencapai 7,59\% pertahun (Badan Statistik Konsumsi Pangan, 2015). Hal ini akan menyebabkan kurangnya tingkat penyediaan semangka di Indonesia. Dimana perkembangan produksi semangka tertinggi di Indonesia mencapai 653.974 ton dengan tingkat 
persentase sebesar 41,97\% pada tahun 2014 dan terjadi peningkatan produksi dari tahun sebelumnya sebesar 193.346 ton. Perkembangan semangka terendah terjadi pada tahun 2010 sebesar 348.631 ton dengan persentase $26,50 \%$ mengalami suatu penurunan produksi.

Jawa Timur merupakan provinsi sentra penghasil semangka terbesar di Indonesia dibandingkan dengan provinsi lain. Tingkat produksi di Jawa Timur pada tahun 2014 sebesar 165.409 ton dengan luas panen sebesar $8.841 \mathrm{Ha}$ dan memiliki tingkat produktivitas sebesar 18,71 ton/ha. Salah satu kabupaten yang berkontribusi pada produksi semangka di Jawa Timur adalah Kabupaten Jember. Kabupaten Jember merupakan daerah yang sebagian besar berada pada area dataran rendah dengan memiliki ketinggian antara 0-500m di atas permukaan laut (dpl). Keadaan tersebut menunjukkan bahwa sangat cocok untuk budidaya tanaman semangka dan dapat tumbuh baik pada dataran rendah hingga dataran tinggi dengan ketinggian 100-300 $\mathrm{m}$ diatas permukaan laut (Prajnanta, 2001). Buah semangka yang terdapat di Kabupaten Jember juga memiliki kelebihan diantaranya buahnya besar, memiliki ketahanan daya simpan, dan rasanya manis. Hal tersebut yang menjadikan semangka dapat diminati oleh masyarakat.

Kecamatan Gumukmas Kabupaten Jember merupakan daerah sentra penghasil semangka ke-2 setelah Kecamatan Puger karena letak geografis dekat dengan pantai serta terdapat lahan berpasir yang sesuai untuk penanaman semangka. Rata-rata produktivitas semangka nonbiji di Kecamatan Gumukmas varietas hibrida quality mencapai 11,722 Ton/Ha dan masih tergolong rendah. Menurut Kalie (2002), tanaman semangka yang dipelihara intensif dan pertumbuhannya baik dapat menghasilkan produktivitas potensial sebesar 20-30 Ton/ha untuk semangka hibrida.

Desa Mayangan merupakan salah satu desa yang terdapat di Kecamatan Gumukmas dengan memiliki tingkat produksi tertinggi, namun produktivitasnya masih rendah. Tingkat produksi semangka di Desa Mayangan mencapai 2.808,2 ton pada tahun 2015 dengan luas lahan \pm 201 Ha. Selama ini masyarakat Desa Mayangan sudah lama membudidayakan semangka, akan tetapi masih saja terjadi kendala diantaranya tingkat produktivitas yang masih rendah, kapasitas produksi yang menurun, kondisi iklim dan cuaca yang tidak menentu. Kapasitas produksi semangka di Desa Mayangan dari tahun 2014-2015 mengalami penurunan yang berkaitan dengan penggunaan faktor produksi. Faktor produksi yang digunakan pada usahatani semangka di Desa Mayangan adalah dapat berupa lahan, lahan sebagai media tanam semangka dimana lahan yang digunakan tanpa adanya suatu pergantian tanaman lain sehingga dapat menurunkan tingkat kesuburan tanah. Menurut Kalie (2002), jika suatu lahan digunakan tanpa adanya pergantian tanaman lain atau tanpa adanya pengolahan lahan akan berpengaruh terhadap jumlah produksi yang dihasilkan pada usahatani.

Jika dilihat dari tingkat produktivitas, produktivitas semangka di Desa Mayangan sebesar 13,971 ton/ha. Keadaan tersebut menunjukkan bahwa tingkat produktivitas masih rendah di bawah rata-rata tingkat nasional sebesar 18,71 ton/ha. Menurut Soekartawi (1987) dalam Shinta (2011) tingkat produktivitas usahatani akan semakin tinggi jika petani atau produsen mampu mengalokasikan faktor produksi berdasarkan prinsip efisiensi teknis dan dapat dilakukan pengelolaan yang tepat dalam usahatani. Selain alokasi input, tingkat efisiensi dapat dipengaruhi oleh kemampuan manajerial petani. Kemampuan manajerial dari diri petani yaitu umur petani, pengalaman usahatani, tingkat pendidikan formal maupun nonformal yang melalui pelatihan budidaya dan pengolahan usahatani, keanggotaan dalam kelompok tani, akses kepada sumber pembiayaan usahatani dan lain-lain. Hal ini akan mempengaruhi kemampuan manjerial petani pada produksi semangka sehingga akan berpengaruh pada tingkat efisiensi usahatani semangka.

Adapun tujuan dari penelitian ini adalah untuk mengetahui faktor-faktor yang mempengaruhi tingkat produksi, tingkat efisiensi teknis, dan faktor-faktor yang mempengaruhi tingkat inefisiensi teknis usahatani semangka di Desa Mayangan Kecamatan Gumukmas Kabupaten Jember agar tercapai kegiatan usahatani semangka yang mampu meningkatkan produktivitas usahatani semangka.

\section{METODOLOGI PENELITIAN}

Metode penentuan daerah penelitian berdasarkan metode purposive method. Purposive Method adalah penentuan lokasi penelitian dilakukan secara sengaja. Daerah yang dipilih sebagai daerah penelitian adalah Desa Mayangan Kecamatan Gumukmas. Pemilihan daerah penelitian didasarkan atas pertimbangan bahwa daerah tersebut merupakan salah satu penghasil semangka dengan tingkat produksi tertinggi yang memiliki lahan yang luas diantara desa yang lain.

Metode yang digunakan dalam penelitian ini adalah deskriptif, korelasi dan analitis. Metode deskriptif merupakan penelitian yang berusaha mendeskripsikan, menjawab pertanyaan sehubungan dengan penelitian dan menginterpretasikan sesuatu. Metode analitis adalah pengujian hipotesis dan mengadakan interpretasi yang lebih dalam mengenai hipotesis yang telah dibuat. Tujuan dari metode 
analitis untuk menguji kebenaran dari hipotesis yang diajukan dalam penelitian (Nazir, 2003). Metode korelasi adalah metode penelitian untuk mengetahui tingkat hubungan antara dua variabel atau lebih tanpa melakukan perubahan, tambahan, atau manipulasi terhadap data yang memang sudah ada (Arikunto, 2013).

Metode pengambilan contoh yang digunakan dalam penelitian ini yaitu Proportionate Stratafied Random Sampling. Menurut Sugiyono (2014), teknik ini digunakan bila populasi mempunyai anggota atau unsur untuk tidak homogen dan berstrata secara proporsional. Besarnya sampel petani ditentukan dengan menggunakan rumus Slovin.

Tabel 1. Pembagian Strata Petani Semangka menurut Luas Lahan di Desa Mayangan Kecamatan Gumukmas

\begin{tabular}{lrrr}
\hline Strata & $\begin{array}{c}\text { Kriteria } \\
\text { Luas Lahan } \\
(\mathrm{Ha})\end{array}$ & Populasi & Sampel \\
\hline Sempit & $<1$ & 187 & 29 \\
Sedang & $1-2$ & 110 & 17 \\
Luas & $>2$ & 18 & 4 \\
\hline Total & & 315 & 50 \\
\hline
\end{tabular}

Sumber: UPTD Kecamatan Gumukmas, 2016.

Metode pengumpulan data yang digunakan untuk pengumpulan data primer adalah metode wawancara dan obesrvasi. Pengumpulan data dilakukan dengan melakukan wawancara langsung kepada responden dengan menggunakan kuisioner sebagai panduan wawancara. Metode pengumpulan data yang digunakan untuk pengumpulan data sekunder adalah teknik dokumentasi.

Untuk mengetahui tujuan mengenai faktor-faktor yang mempengaruhi produksi di Desa Mayangan Kecamatan Gumukmas Kabupaten Jember di analisis menggunakan pendekatan fungsi produksi Stochastic Frontier Cobb-Douglas dengan pengolahan data menggunakan aplikasi Frontier 4.1 dengan metode MLE (Maximum Likelihood Estimation). Bentuk dari persamaan Stochastic Frontier Cobb-Douglas dalam bentuk logaritma natural adalah sebagai berikut :

$L n Y=\ln \beta_{0}+\beta_{1} \ln X_{1}+\beta_{2} \ln X_{2}+\beta_{3} \ln X_{3}+\beta_{4} \ln X_{4}+$

Keterangan:

$$
\beta_{5} \ln X_{5}+\beta_{6} \ln X_{6}+\beta_{7} \ln X_{7}
$$

$\mathrm{Y}=$ Produksi Semangka (Ton)

$\beta_{0}=$ Intersep

$\beta_{\mathrm{i}}=$ Koefisien parameter penduga, dimana $\mathrm{i}=1,2$, $3, \ldots . .7$

$\mathrm{X}_{1}=$ Luas lahan $(\mathrm{Ha})$

$\mathrm{X}_{2}=$ Tenaga Kerja (HOK)

$\mathrm{X}_{3}=$ Pupuk Organik $(\mathrm{Kg})$

$\mathrm{X}_{4}=$ Pupuk Kimia $(\mathrm{Kg})$

$\mathrm{X}_{5}=$ Bibit (Polibag)
$\mathrm{X}_{6}=$ Pestisida Cair $(\mathrm{mL})$

$\mathrm{X}_{7}=$ Pestisida Padat $(\mathrm{Kg})$

Pengujian asumsi klasik dilakukan setelah dilakukan estimasi model regresi linier berganda. Pengujian asumsi klasik meliputi uji multikolinearitas, heterokedastisitas, normalitas, dan autokorelasi dengan aplikasi SPSS. Selanjutnya, dilakukan uji kelayakan model apabila telah memenuhi semua uji asumsi klasik tersebut. Uji kelayakan model dilakukan dengan uji-t. Uji-t dilakukan untuk membandingkan nilai t-hitung dengan t-tabel yaitu:

Kriteria pengambilan keputusan pada tingkat signifikansi 5\%:

1. thitung $<\mathrm{t}_{\text {tabel }}, \mathrm{H}_{0}$ diterima artinya secara parsial variabel independen tidak berpengaruh secara signifikan terhadap produksi semangka.

2. thitung $>t_{t a b e l}, H_{1}$ diterima artinya secara parsial variabel independen berpengaruh secara signifikan terhadap produksi semangka.

Setelah itu dapat dilanjutkan dengan melakukan pengujian estimasi parameter pada persamaan stochastic frontier analysis cobb-dauglass. Estimasi dilakukan menggunakan penaksir (estimator) maximum likelihood (MLE). Langkah selanjutnya melakukan pengujian dan melihat kelayakan model. Kelayakan model dapat dilihat melalui sigma-squared $\left(\sigma^{2}\right)$, nilai gamma $(\gamma)$ dan pengujian terhadap nilai variansi efek inefisiensi teknis $\left(\sigma_{\mathrm{u}}^{2}\right)$. Selanjutnya dapat dilakukan pengujian kedua mengenai likelihood rasio-test $(\lambda)$, pengujian ini dilakukan bertujuan untuk mengetahui model apakah yang digunakan baik atau belum. Fungsi log-likelihood yang dimaksud adalah sebagai berikut:

$$
\mathrm{LR}=-2[\ln (\mathrm{Lr})-\ln (\mathrm{Lu})]
$$

Dengan hipotesis sebagai berikut:

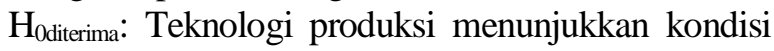
Constants return to Scale

$\mathrm{H}_{\text {lditerima: }}$ Teknologi produksi tidak menunjukkan kondisi Constants return to Scale

Nilai perhitungan LR kemudian dibandingkan dengan nilai kritis $\mathrm{x} 2$. Sedangkan kriteria uji yang digunakan adalah uji generalized likelihood-ratio satu arah, dengan persamaan uji sebagai berikut:

1. $\mathrm{LR}_{\text {hitung }}>\mathrm{X}^{2}$ restriksi (tabel kodde dan palm) maka $\mathrm{H}_{0}$ ditolak

2. $\mathrm{LR}_{\text {hitung }}<\mathrm{X}^{2}$ restriksi (tabel kodde dan palm) maka $\mathrm{H}_{0}$ diterima

Untuk mengetahui tujuan mengenai efisiensi teknis dilakukan untuk mengetahui tingkat penggunaan input pada produksi usahatani semangka di Desa Mayangan Kecamatan Gumukmas yang sebenarnya dengan tingkat produksi maskimum dengan menggunakan analisis Stochastic Frontier. 
Rumus yang digunakan untuk menentukan nilai efisiensi teknis:

$$
\mathrm{TEi}=\mathrm{Yi} / \mathrm{Yi}^{*}
$$

Keterangan:

$\mathrm{TEi}=$ Efisiensi teknis petani ke-i,

Yi $\quad=$ Output riil petani ke-i

$\mathrm{Yi}^{*} \quad=$ Output Frontier petani ke-i

Kriteria pengambilan keputusan (Coelli, 1998):

1. Jika nilai indeks efisiensi $<0,7$ maka usahatani semangka belum efisien secara teknis

2. Jika nilai indeks efisiensi $\geq 0.7$, maka usahatani semangka efisien secara teknis

Untuk mengetahui tujuan mengenai faktor-faktor inefisiensi teknis dalam usahatani semangka dapat dianalisis dengan Stochastic Frontier Analysis dengan rumus:

$$
\mu=\delta_{0}+\delta_{1} Z_{1}+\delta_{2} Z_{2}+\underset{D_{K L}}{\delta_{3} Z_{3}+\delta_{4} Z_{4}+\delta_{5} D_{\mathrm{KK}}+\delta_{6}}
$$

Keterangan:

$$
\begin{array}{ll}
\mu & =\text { efek inefisiensi teknis } \\
\delta_{0} & =\text { konstanta } \\
\delta_{1}-\delta_{6} & =\text { koefisien parameter } \\
\mathrm{Z}_{1} & =\text { umur petani (tahun) } \\
\mathrm{Z}_{2} & =\text { pengalaman usahatani semangka (tahun) } \\
\mathrm{Z}_{3} & =\text { jumlah anggota keluarga (orang) } \\
\mathrm{Z}_{4} & =\text { pendidikan petani (tahun) } \\
\mathrm{D}_{\mathrm{KK}} & =\text { dummy keikutsertaan dalam kelompok } \\
& \text { tani }(0=\text { bukan anggota } 1=\text { anggota) } \\
\mathrm{D}_{\mathrm{KL}} & =\text { dummy kepemilikan lahan }(0=\text { sewa, } 1= \\
& \text { sendiri) }
\end{array}
$$
lain:

Berikut kriteria pengambilan keputusan antara

1. $t_{\text {hitung }}<\mathrm{t}_{\text {tabel }}, \mathrm{H}_{0}$ diterima artinya suatu variabel independen secara parsial tidak mempengaruhi variabel dependen.
2. $t_{\text {hitung }}>t_{\text {tabel }}, \mathrm{H}_{1}$ diterima artinya suatu variabel independen secara parsial mempengaruhi variabel dependen.

\section{HASIL DAN PEMBAHASAN}

\section{Faktor-faktor yang Mempengaruhi Produksi Semangka di Desa Mayangan}

Faktor-faktor produksi yang digunakan dalam usahatani semangka di Desa Mayangan pada bulan Maret-Mei 2017 meliputi luas lahan $\left(X_{1}\right)$, tenaga kerja $\left(\mathrm{X}_{2}\right)$, pupuk organik $\left(\mathrm{X}_{3}\right)$, pupuk kimia $\left(\mathrm{X}_{4}\right)$, bibit $\left(\mathrm{X}_{5}\right)$, pestisida cair $\left(\mathrm{X}_{6}\right)$, dan pestisida padat $\left(\mathrm{X}_{7}\right)$. Fungsi produksi yang digunakan dalam penelitian ini adalah fungsi produksi Stochastic Frontier CobbDouglas. Hasil dari pendugaan fungsi produksi tersebut akan digunakan untuk menganalisis faktorfaktor produksi yang mempengaruhi produksi usahatani semangka di Desa Mayangan serta menganalisis tingkat efisiensi teknis dan faktor yang mempengaruhi inefisiensi teknis semangka di Desa Mayangan Kecamatan Gumukmas. Pendugaan parameter dilakukan dengan 2 tahap yaitu dengan metode Ordinary Least Square (OLS) dan Maksimum Likelihood Estimation (MLE). Pengujian dengan metode OLS juga dapat mendeteksi normalitas, autokorelasi, multikolinearitas, dan heteroskedastisitas dalam fungsi produksi. Tahap kedua menggunakan metode MLE untuk menggambarkan kinerja terbaik (best practice) dari petani dalam melakukan proses produksi semangka. Penyelesain tersebut dapat dilakukan dengan aplikasi Frontier 4.1

Tabel 2. Pendugaan model fungsi produksi semangka dengan metode OLS

\begin{tabular}{lrrr}
\multicolumn{1}{c}{ Variabel } & \multicolumn{2}{c}{ Standard eror } & t-ratio \\
\hline Intersep & $-1,558$ & 1,754 & $-0,888$ \\
Luas lahan & 0,729 & 0,208 & $3,503^{*}$ \\
Tenaga kerja & 0,662 & 0,233 & $2,837^{*}$ \\
Pupuk organik & $-0,195$ & 0,091 & $-2,131^{*}$ \\
Pupuk kimia & $-0,158$ & 0,122 & $-1,301$ \\
Bibit & 0,268 & 0,155 & 1,726 \\
Pestisida cair & 0,034 & 0,036 & 0,951 \\
Pestisida padat & 0,052 & 0,075 & 0,690 \\
\hline Siqma Squared & & & 0,087 \\
Log-likelihood ratio & & & $-5,523$ \\
Anti Ln -1,558 & & & 0,210 \\
\hline t-tabel & & 2,016 \\
\hline LR-tabel & & & 14,853 \\
\hline
\end{tabular}

Sumber: Data primer diolah (2017)

Keterangan: *) berpengaruh nyata pada taraf kesalahan 5\%

Pendugaan fungsi produksi dengan menggunakan metode OLS pada aplikasi Frontier 
4.1. Pengujian OLS digunakan untuk ketepatan model. Hasil analisis tersebut menunjukkan bahwa produksi semangka tanpa adanya perubahan variabel luas lahan, tenaga kerja, pupuk organik, pupuk kimia, bibit, pestisida cair, dan pestisida padat adalah sebesar 0,210 ton. Hasil perhitungan dari tujuh variabel bebas yang ada pada model, terdapat tiga variabel yang berpengaruh nyata terhadap produksi semangka yaitu luas lahan $\left(\mathrm{X}_{1}\right)$, tenaga kerja $\left(\mathrm{X}_{2}\right)$ dan pupuk organik $\left(\mathrm{X}_{3}\right)$.

Hasil pendugaan tahap kedua yaitu pendugaan model fungsi produksi dengan menggunakan metode MLE. Hasil pendugaan tersebut menggambarkan kinerja terbaik dari petani responden pada tingkat teknologi yang ada. Hasil perhitungan regresi berganda dengan menggunakan metode MLE melalui aplikasi Frontier 4.1 dapat dilihat pada Tabel 2 berikut:

Tabel 3. Pendugaan model fungsi produksi semangka dengan metode MLE

\begin{tabular}{|c|c|c|c|}
\hline Variabel & Koefisien & Standard eror & t-ratio \\
\hline Intersep & 0,270 & 1,040 & 0,260 \\
\hline Luas lahan & 0,695 & 0,131 & $5,319^{*}$ \\
\hline Tenaga kerja & 0,377 & 0,185 & $2,039^{*}$ \\
\hline Pupuk organik & $-0,175$ & 0,078 & $-2,230^{*}$ \\
\hline Pupuk kimia & $-0,206$ & 0,084 & $-2,458^{*}$ \\
\hline Bibit & 0,335 & 0,096 & $3,492^{*}$ \\
\hline Pestisida cair & 0,024 & 0,022 & 1,098 \\
\hline Pestisida padat & 0,028 & 0,038 & 0,757 \\
\hline Siqma Squared & 0,070 & 0,023 & $3,017^{*}$ \\
\hline Gamma & 0,960 & 0,054 & $17,855^{*}$ \\
\hline Log-likelihood ratio & & & $8,731^{*}$ \\
\hline LR-test of the one sided error & & & $28,508^{*}$ \\
\hline Anti-Ln 0,270 & & & 1,310 \\
\hline t-tabel & & & 2,016 \\
\hline LR-tabel & & & 14,853 \\
\hline
\end{tabular}

Sumber: Data primer diolah (2017)

Keterangan: *) berpengaruh nyata pada taraf kesalahan $5 \%$

Berdasarkan hasil dapat dilihat nilai $\log _{-}$ likelihood ratio dengan metode MLE sebesar 8,731 adalah lebih besar dari nilai Log-likelihood ratio dengan metode OLS sebesar $-5,523$ yang berarti fungsi produksi dengan metode MLE ini adalah bagus. Faktor-faktor yang secara signifikan mempengaruhi produksi semangka pada taraf kesalahan 5\% terdiri dari luas lahan, tenaga kerja, pupuk organik, pupuk kimia, dan bibit. Parameter lain yang perlu diperhatikan dalam fungsi produksi Frontier Stochastic Cobb-Douglas adalah nilai gamma dan LR test of one side error. Persamaan atau fungsi produksi Frontier Stochastic Cobb-Douglas yaitu:

\section{$\operatorname{Ln} \mathrm{Y}=0,270+0,695 \operatorname{LnX} 1+0,377 \operatorname{LnX} 2-0,175$$$
\text { LnX3 - 0,206 LnX4 + 0,335 LnX5 + 0,024 }
$$$$
\text { LnX6 + 0,028LnX7+ Vi - Ui }
$$

Persamaan tersebut diestimasi dalam bentuk persamaan linier, untuk merubahnya kembali menjadi bentuk persamaan non linier maka dilakukan antilogaritma, sehingga bentuk persamaannya menjadi sebagai berikut:

\section{$\mathbf{Y} \underset{{ }^{0,206} \mathbf{X}_{5}}{=} \underset{{ }^{0,335} \mathbf{X}_{6}{ }^{0,024} \mathbf{X}_{7}}{1,310} \mathbf{X}_{{ }^{0,028}}{ }^{0,695} \mathbf{X}_{2}{ }^{0,377} \mathbf{X}_{3}{ }^{-0,175} \mathbf{X}_{4}$}

Berdasarkan hasil analisis tersebut menunjukkan bahwa produksi semangka tanpa adanya penambahan variabel luas lahan, tenaga kerja, pupuk organik, pupuk kimia, bibit, pestisida cair, dan pestisida padat adalah sebesar 1,310 ton. Pengujian selanjutnya adalah interpretasi secara individu masing-masing variabel bebas (luas lahan, tenaga kerja, pupuk organik, pupuk kimia, bibit, pestisida cair, dan pestisida padat) terhadap produksi semangka. Berikut adalah hasil pengujian secara individual dari hasil analisis fungsi stochastic frontier Cobb-douglas adalah:

\section{a. Luas lahan $\left(\mathbf{X}_{1}\right)$}

Koefisien regresi variabel luas lahan adalah 0,695 . Tanda positif tersebut menunjukkan bahwa pengaruh perubahan variabel luas lahan berbanding lurus terhadap produksi semangka. Hasil pengujian secara individual (uji-t) dengan metode MLE variabel luas lahan diperoleh nilai thitung sebesar 5,319> t-tabel 2,016. Nilai tersebut menunjukkan bahwa variabel luas lahan secara 
parsial berpengaruh nyata terhadap produksi semangka dengan taraf kesalahan $5 \%$. Artinya, dengan asumsi ceteris paribus setiap penambahan $1 \%$ faktor produksi luas lahan maka akan menambah produksi semangka sebesar $0,695 \%$. Nilai koefisien tersebut juga menunjukkan elastisitas penggunaan faktor produksi luas lahan. Nilai 0,695 menunjukkan bahwa penggunaan faktor produksi luas lahan berada pada elastisitas $0<$ Ep $<1$, nilai tersebut menunjukkan bahwa penggunaan luas lahan berada pada daerah rasional, artinya pada daerah ini petani telah menggunakan input luas lahan secara optimal.

Faktor luas lahan memiliki koefisien yang positif terhadap produksi semangka. Pengaruh lahan yang cukup besar terhadap produksi semangka karena lahan yang terdapat di daerah penelitian termasuk lahan berpasir dan cocok untuk tanaman semangka. Perluasan lahan di daerah penelitian dapat dilakukan dengan cara ekstensifikasi lahan. Namun, pada kondisi di lapangan penambahan luas lahan ini tidak mudah. Hal ini dikarenakan tanah atau lahan yang terdapat dalam penelitian merupakan tanah bengkok (tanah milik pemerintah) dan jumlahnya terbatas dengan banyaknya penggunaan lahan untuk perumahan. Hasil penelitian ini didukung oleh penelitianpenelitian lain seperti Niam (2014), Putri (2010), dan Laksmayani (2013).

\section{b. Tenaga kerja $\left(\mathbf{X}_{2}\right)$}

Koefisien regresi variabel tenaga kerja adalah 0,377 . Tanda positif tersebut menunjukkan bahwa pengaruh perubahan variabel tenaga kerja berbanding lurus terhadap produksi semangka. Hasil pengujian secara individual (uji-t) dengan metode MLE variabel tenaga kerja diperoleh nilai t-hitung sebesar 2,039> t-tabel 2,016. Nilai tersebut menunjukkan bahwa variabel tenaga kerja secara parsial berpengaruh nyata terhadap produksi semangka dengan taraf kesalahan $5 \%$. Artinya, dengan asumsi ceteris paribus setiap penambahan $1 \%$ faktor produksi tenaga kerja maka akan menambah produksi semangka sebesar $0,377 \%$. Nilai koefisien tersebut juga menunjukkan elastisitas penggunaan faktor produksi tenaga kerja. Nilai 0,377 menunjukkan bahwa penggunaan faktor produksi tenaga kerja berada pada elastisitas $0<E p<1$, nilai tersebut menunjukkan bahwa penggunaan tenaga kerja berada pada daerah rasional, artinya pada daerah ini petani telah menggunakan input tenaga kerja secara optimal.

Tenaga kerja merupakan unsur penentu, terutama bagi usahatani yang sangat tergantung pada musim. Kelangkaan tenaga kerja berpengaruh pada pertumbuhan tanaman, produktivitas, dan kualitas produk (Suratiyah, 2015). Ketersediaan tenaga kerja di daerah penelitian relatif banyak dan mudah didapatkan. Rata-rata tenaga kerja dalam usahatani semangka berasal dari dalam keluarga. Tenaga kerja yang digunakan dalam usahatani semangka menggunakan satuan HOK yang terdiri dari tenaga kerja wanita dan pria. Rata-rata tenaga kerja yang dibutuhkan untuk melakukan usahatani semangka dalam satuan hektar adalah 367,74 atau 368 HOK yang terdiri tenaga kerja wanita sebesar 116 HOK dan 252 HOK. Kegiatan yang paling banyak membutuhkan tenaga kerja dalam usahatani semangka adalah kegiatan penyiraman rata-rata tenaga kerja yang dibutuhkan dalam kegiatan ini sebesar 110 HOK. Kegiatan yang paling sedikit membutuhkan tenaga kerja dalam usahatani semangka adalah kegiatan pembuangan wiwil. Dimana tenaga kerja yang dibutuhkan ratarata sebesar 17 HOK.

Kegiatan penyiraman menjadi salah satu kegiatan yang terpenting karena tanaman semangka membutuhkan kandungan air yang cukup tinggi, sehingga jangan sampai tanaman semangka tidak terpenuhi kandungan air karena dapat menyebabkan kematian. Penambahan tenaga kerja sangat diperlukan untuk intensifikasi pemeliharaan, seperti pembuangan wiwil, pembuahan, pemangkasan, penyiraman, dan pengendalian hama karena usahatani semangka merupakan jenis usahatani yang membutuhkan penanganan yang detail agar tanaman semangka dapat tumbuh secara optimal. Upaya penambahan yang dilakukan dapat berupa penambahan jam kerja pada kegiatan penyiraman dan pengendalian hama maupun penambahan jumlah pekerja pada kegiatan pembuangan wiwil, pembuahan dan pemangkasan. Hal yang perlu diperhatikan dalam penambahan tenaga kerja perlu dilihat dari tingkat keterampilan pekerja yang akan berpengaruh terhadap peningkatan produksi semangka. Hasil penelitian ini didukung oleh penelitian Putri (2010).

\section{c. Pupuk organik $\left(\mathbf{X}_{3}\right)$}

Koefisien regresi variabel pupuk organik adalah -0,175. Tanda negatif tersebut menunjukkan bahwa pengaruh perubahan variabel pupuk organik berbanding terbalik terhadap produksi semangka. Hasil pengujian secara individual (uji-t) dengan metode MLE variabel pupuk organik diperoleh nilai t-hitung sebesar 2,230> t-tabel 2,016. Nilai tersebut menunjukkan bahwa variabel pupuk organik secara parsial berpengaruh nyata terhadap produksi semangka 
dengan taraf kesalahan $5 \%$. Artinya, dengan asumsi ceteris paribus setiap penambahan $1 \%$ faktor produksi pupuk organik maka akan menurunkan produksi semangka sebesar $0,175 \%$. Nilai koefisien tersebut juga menunjukkan elastisitas penggunaan faktor produksi pupuk organik. Nilai $-0,175$ menunjukkan bahwa penggunaan faktor produksi pupuk organik berada pada elastisitas Ep $<0$, nilai tersebut menunjukkan bahwa penggunaan pupuk organik berada pada daerah irrasional, artinya pada daerah ini petani terlalu banyak menggunakan input pupuk organik sehingga pada daerah tersebut tidak memungkinkan petani untuk menambah produksi pupuk organik, karena penambahan pupuk organik akan menurunkan produksi semangka.

Penggunaan pupuk organik dalam usahatani semangka di Desa Mayangan yang dianjurkan oleh Dinas UPTD Kecamatan Gumukmas sebesar $600 \mathrm{~kg} / \mathrm{ha}$, sementara rata-rata yang digunakan petani sebesar $651 \mathrm{~kg} / \mathrm{ha}$. Pemberian pupuk organik di Desa Mayangan dalam usahatani semangka bertujuan untuk memperbaiki struktur tanah, menaikkan daya serap tanah terhadap air, menaikkan kondisi kehidupan mikroorganisme di dalam tanah, merangsang pertumbuhan akar, dan meningkatkan produksi tanaman semaksimal mungkin. Tetapi, hal tersebut tidak dapat memberikan manfaat terhadap tingkat produksi semangka karena pengaplikasian pupuk organik pada daerah penelitian tidak sesuai SOP. Penggunaan pupuk organik pada daerah penelitian dapat dilakukan dengan proses pengolahan tanah dan didiamkan selama 1-2 hari. Menurut SOP seharusnya pemberian pupuk organik dapat dilakukan dengan proses pengolahan tanah dan dilakukan pendiaman selama satu minggu.

\section{d. Pupuk kimia $\left(\mathrm{X}_{4}\right)$}

Koefisien regresi variabel pupuk kimia adalah $-0,206$. Tanda negatif tersebut menunjukkan bahwa pengaruh perubahan variabel pupuk kimia berbanding terbalik terhadap produksi semangka. Hasil pengujian secara individual (uji-t) dengan metode MLE variabel pupuk kimia diperoleh nilai t-hitung sebesar 2,458> t-tabel 2,016. Nilai tersebut menunjukkan bahwa variabel pupuk kimia secara parsial berpengaruh nyata terhadap produksi semangka dengan taraf kesalahan $5 \%$. Artinya, dengan asumsi ceteris paribus setiap penambahan $1 \%$ faktor produksi pupuk kimia maka akan menurunkan produksi semangka sebesar 0,206\%. Nilai koefisien tersebut juga menunjukkan elastisitas penggunaan faktor produksi pupuk kimia. Nilai -0,206 menunjukkan bahwa penggunaan faktor produksi pupuk kimia berada pada elastisitas $\mathrm{Ep}<0$, nilai tersebut menunjukkan bahwa penggunaan pupuk kimia berada pada daerah irrasional, artinya pada daerah ini petani terlalu banyak menggunakan input pupuk kimia sehingga pada daerah tersebut tidak memungkinkan petani untuk menambah produksi pupuk kimia, karena penambahan pupuk kimia akan menurunkan produksi semangka.

Rata-rata penggunaan pupuk kimia (Phonsak, $\mathrm{Za}$, NPK, KNO3, Urea, ZK, dan SP36) yang digunakan dalam usahatani semangka oleh petani adalah $1.513 \mathrm{~kg} / \mathrm{ha}$. Penggunaan pupuk kimia yang dianjurkan oleh Dinas UPTD Kecamatan Gumukmas dari penyuluh sesuai buku pedoman adalah sekitar $1.020 \mathrm{~kg} / \mathrm{ha}$ untuk semua jenis pupuk kimia. Keadaan di daerah penelitian dilihat dari $\mathrm{pH}$ tanah di Desa Mayangan yang berkisar antara 5,5-6, sehingga tanah dapat dikatakan mempunyai sifat asam. Keasaman tanah $(\mathrm{pH})$ yang diperlukan untuk tanaman semangka antara 6-6,7 (Prajnanta,2001). Tingkat keasaman tanah dapat meningkat dikarenakan penggunaan pupuk yang dapat berpengaruh mengasamkan tanah seperti Urea, ZA, Amonium Sulfat, Kcl, dan ZK. Akibat dari tanah masam yaitu menyebabkan penurunan ketersediaan unsur hara bagi tanaman, meningkatkan dampak unsur hara bagi tanaman, dan penurunan hasil tanaman.

\section{e. $\quad$ Bibit $\left(\mathbf{X}_{5}\right)$}

Koefisien regresi variabel bibit adalah 0,335. Tanda positif tersebut menunjukkan bahwa pengaruh perubahan variabel bibit berbanding lurus terhadap produksi semangka. Hasil pengujian secara individual (uji-t) dengan metode MLE variabel bibit diperoleh nilai t-hitung sebesar $3,492>$ t-tabel 2,016. Nilai tersebut menunjukkan bahwa variabel bibit secara parsial berpengaruh nyata terhadap produksi semangka dengan taraf kesalahan $5 \%$. Artinya, dengan asumsi ceteris paribus setiap penambahan $1 \%$ faktor produksi bibit maka akan menambah produksi semangka sebesar $0,335 \%$. Nilai koefisien tersebut juga menunjukkan elastisitas penggunaan faktor produksi bibit. Nilai 0,335 menunjukkan bahwa penggunaan faktor produksi bibit berada pada elastisitas $0<\mathrm{Ep}<1$, nilai tersebut menunjukkan bahwa penggunaan bibit berada pada daerah rasional, artinya pada daerah ini petani telah menggunakan input bibit secara optimal.

Peningkatan produksi semangka dengan penambahan jumlah bibit memiliki proporsi yang cukup besar. Penggunaan bibit semangka yang masih memungkinkan untuk ditambah ini diasumsikan terjadi karena jarak tanam yang digunakan belum optimal. Rata-rata jarak tanam 
yang digunakan oleh petani yaitu $65-70 \mathrm{~cm}$. Berdasarkan literatur, jarak tanaman ideal untuk tanaman semangka adalah $60-65 \mathrm{~cm}$. Hal ini menunjukkan bahwa petani dapat menambah jumlah bibit dengan memperpendek jarak tanam. Pemilihan kualitas bibit juga sangat menentukan dalam keberhasilan usahatani semangka. Hal ini dapat didukung oleh penelitian Apriani (2001).

\section{f. Pestisida cair $\left(\mathbf{X}_{6}\right)$}

Koefisien regresi variabel pestisida cair adalah 0,024 . Tanda positif tersebut menunjukkan bahwa pengaruh perubahan variabel pestisida cair berbanding lurus terhadap produksi semangka. Hasil pengujian secara individual (uji-t) dengan metode MLE variabel pestisida cair diperoleh nilai t-hitung sebesar $1,098<\mathrm{t}$-tabel 2,016. Nilai tersebut menunjukkan bahwa variabel pestisida cair secara parsial tidak berpengaruh nyata terhadap produksi semangka dengan taraf kesalahan $5 \%$. Artinya, dengan asumsi ceteris paribus setiap penambahan $1 \%$ faktor produksi pestisida cair maka akan menambah produksi semangka sebesar $0,024 \%$. Nilai koefisien tersebut juga menunjukkan elastisitas penggunaan faktor produksi pestisida cair. Nilai 0,024 menunjukkan bahwa penggunaan faktor produksi pestisida cair berada pada elastisitas $0<\mathrm{Ep}<1$, nilai tersebut menunjukkan bahwa penggunaan pestisida cair berada pada daerah rasional, artinya pada daerah ini petani telah menggunakan input pestisida cair secara optimal.

Pestisida cair merupakan jenis obat insektisida yang digunakan dalam usahatani semangka di Desa Mayangan. Pestisida cair sangat dibutuhkan untuk budidaya buah semangka, dalam melakukan kegiatan budidaya semangka petani selalu menemui berbagai hambatan seperti adanya hama thrips, ulat buah, dan ulat perusak daun. Hama yang terdapat dilapang dapat menyerang pada daun menjadi kekuningan maupun buah menjadi busuk. Variasi jenis pestisida cair dapat berupa regent, prevaton,resotin, marsal, demolish, supergo, multitonik, dan greentonik.

\section{g. Pestisida padat $\left(\mathbf{X}_{7}\right)$}

Koefisien regresi variabel pestisida padat adalah 0,028 . Tanda positif tersebut menunjukkan bahwa pengaruh perubahan variabel pestisida padat berbanding lurus terhadap produksi semangka. Hasil pengujian secara individual (uji-t) dengan metode MLE variabel pestisida padat diperoleh nilai t-hitung sebesar $\quad 0,757<\mathrm{t}$-tabel 2,016. Nilai tersebut menunjukkan bahwa variabel pestisida padat secara parsial tidak berpengaruh nyata terhadap produksi semangka dengan taraf kesalahan $5 \%$. Artinya, dengan asumsi ceteris paribus setiap penambahan
$1 \%$ faktor produksi pestisida padat maka akan menambah produksi semangka sebesar $0,028 \%$. Nilai koefisien tersebut juga menunjukkan elastisitas penggunaan faktor produksi pestisida padat. Nilai 0,028 menunjukkan bahwa penggunaan faktor produksi pestisida padat berada pada elastisitas $0<\mathrm{Ep}<1$, nilai tersebut menunjukkan bahwa penggunaan pestisida padat berada pada daerah rasional, artinya pada daerah ini petani telah menggunakan input pestisida padat secara optimal.

Pestisida padat adalah bahan aktif yang digunakan petani semangka untuk membunuh jenis fungisida atau jamur. Penyakit yang menyerang tanaman semangka antara lain layu fusarium, bercak daun, busuk buah, dan karat daun. Penanganan penyakit tersebut dapat menggunakan pestisida padat antara lain antracol, dithane, akrobat, multi-kp, kombidor, dan gandasil agar mampu menjaga kualitas buah semangka tetap baik dan pertumbuhan tetap maksimal. Siklus hidup penyakit akan terus berlangsung tanpa henti, akibatnya kerusakan oleh penyakit akan berlangsung terus menerus. Serangan penyakit bisa jadi sangat mempengaruhi terhadap hasil produksi usahatani buah semangka baik kuantitas maupun kualitasnya.

Selanjutnya dalam fungsi stochastic frontier dengan metode MLE (Maximum Likelihood Estimates) dapat dilihat parameter lain yang perlu diperhatikan adalah nilai gamma dan LR test of one side error. Hasil pengujian dengan metode MLE (Maximum Likelihood Estimation) menunjukkan nilai gamma $\left(\gamma=\sigma \mathrm{u}^{2} / \sigma \mathrm{v}^{2}\right)$ menunjukkan perbandingan varian pengaruh inefisiensi teknis dengan varian total (vi) yang ada dalam model. Pada model menunjukkan bahwa nilai gamma sebesar 0,960 atau mendekati 1. Hal ini dapat dikatakan bahwa 96,0\% disebabkan oleh inefisiensi teknis, sedangkan 4,0\% disebabkan oleh kesalahan acak.

Pengujian mengenai nilai likelihood ratio (LR), bertujuan untuk mengetahui pencapain efisiensi teknis secara keseluruhan. Hasil analisis menunjukkan nilai LR sebesar 28,508. Pengujian nilai LR juga dapat dilakukan dengan menggunakan persamaan:

$$
\begin{aligned}
\mathrm{LR} & =-2[\ln (\mathrm{Lr})-\ln (\mathrm{Lu})] \\
\mathrm{LR} & =-2[-5,523-(8,731)] \\
& =-2(-14,254)=28,508
\end{aligned}
$$

Hasil perhitungan menunjukkan bahwa nilai LR test of one side error sebesar 28,508 lebih besar dari nilai tabel $\mathrm{X}^{2}$ yaitu 14,853 pada tabel Kodde dan Palm (1986). Maka $\mathrm{H}_{0}$ ditolak yang artinya terdapat efek inefisiensi teknis dalam model fungsi produksi stochastic frontier. 


\section{Efisiensi Teknis Penggunaan Faktor-faktor Produksi Usaha Tani Semangka di Desa Mayangan Kecamatan Gumukmas}

Pengujian mengenai efisiensi teknis dianalisis dengan menggunakan model fungsi produksi stochastic frontier. Tingkat produksi semangka di Desa Mayangan akan mempengaruhi tingkat efisiensi teknis usahatani semangka. Adanya kendala dalam memperoleh output (produksi semangka) membuat petani tidak mampu mendapatkan hasil yang sebenarnya dapat diperoleh (output frontier). Berikut adalah hasil statistik pencapaian efisiensi teknis usahatani semangka di Desa Mayangan.

Tabel 4. Deskripsi Statistik Pencapaian Efisiensi Teknis Usahatani Semangka di Desa Mayangan Pada Bulan Maret-Mei 2017

\begin{tabular}{ccc}
\hline No & $\begin{array}{c}\text { Deskripsi } \\
\text { Statistik }\end{array}$ & $\begin{array}{c}\text { Pencapaian } \\
\text { Efisiensi Teknis }\end{array}$ \\
\hline 1. & Minimum & 0,265 \\
2. & Maksimum & 0,970 \\
3. & Rata-rata & 0,683 \\
\hline
\end{tabular}

Sumber: Data primer diolah (2017)

Hasil pencapaian efisiensi teknis usahatani semangka di Desa Mayangan Kecamatan Gumukmas Kabupaten Jember dapat dilihat baik secara minimum, maksimum, dan rata-rata efisiensi teknisnya. Pencapaian efisiensi teknis minimal dari usahatani semangka adalah 0,265 yang artinya petani mampu memproduksi semangka $26,5 \%$ dari tingkat produksi potensial yang bisa dicapai. Pencapaian efisiensi teknis maksimum usahatani semangka adalah 0,970 artinya petani semangka mampu memproduksi semangka $97,0 \%$ dari produksi semangka potensial yang bisa dicapai. Pencapaian efisiensi teknis rata-rata untuk usahatani semangka sebesar 0,683 atau $68,3 \%$ dari produksi maksimum. Keadaan tersebut menunjukkan bahwa masih terdapat peluang petani semangka untuk meningkatkan produksi sebesar $31,7 \%$ untuk mencapai produksi maksimum. Hal ini menunjukkan rata-rata sampel petani semangka dapat dikatakan belum efisien secara teknis dikarenakan nilai rata-rata $0,683<0,7$. Petani yang belum efisien secara teknis dapat meningkatkan manajemen dan teknis budidaya usahatani semangka karena memiliki potensi dalam produksi yang seharusnya dicapai serta peluang untuk peningkatan produksi. Tingkat pencapaian efisiensi secara teknis juga dapat dilihat dari tingkat luas lahan yang dimiliki oleh petani semangka di Desa Mayangan. Berikut sebaran petani semangka sesuai dengan luas lahan:

Tabel 5. Sebaran Efisiensi Teknis Menurut Tingkatan Luas Lahan di Desa Mayangan

\begin{tabular}{crrrr}
\hline Luas Lahan (ha) & Jumlah & $\sum$ Efisiensi Teknis & $\begin{array}{c}\text { Rata-rata Efisiensi } \\
\text { teknis }\end{array}$ & Kategori \\
\hline Sempit $(<1)$ & 29 & 17,871 & 0,616 & Belum Efisien \\
Sedang (1-2) & 17 & 12,145 & 0,714 & Efisien \\
Luas (>2) & 4 & 3,464 & 0,866 & Efisien \\
\hline Jumlah & $\mathbf{5 0}$ & & & \\
\hline
\end{tabular}

Sumber: Olahan data primer (2017)

Pencapaian efisiensi teknis menurut luas lahan petani semangka. Petani semangka yang memiliki luas lahan <1 ha (sempit) sebanyak 29 petani dengan rata-rata efisiensi teknis sebesar 0,654. Nilai tersebut menunjukkan bahwa usahatani semangka mampu mencapai $65,4 \%$ dari produksi semangka potensial yang bisa dicapai. Petani yang memiliki luas lahan sempit dapat dikatakan belum efisien secara teknis karena nilai efisiensi $<0,7$. Hal ini menunjukkan bahwa tingkat luas lahan yang semakin sempit akan mempermudah petani dalam mengelola usahatani semangka. Tetapi, dalam kondisi penelitian petani yang memiliki luas lahan sempit semakin belum efisien secara teknis dikarenakan petani di Desa Mayangan dalam penggunaan input produksi lebih boros dibandingkan dengan luas lahan yang luas. Penggunaan input pupuk kimia untuk lahan paling sempit $(0,25 \mathrm{ha})$ membutuhkan $500 \mathrm{~kg}$ sedangkan untuk lahan yang paling luas (3,5 ha) membutuhkan $3.700 \mathrm{~kg}$. Pemakaian pupuk kimia sesuai anjuran dari penyuluh sebesar $1.020 \mathrm{~kg} / \mathrm{ha}$.

Petani semangka yang memiliki luas lahan 12 ha (sedang) adalah 17 petani dari sampel petani semangka dengan rata-rata efisiensi teknis 0,655 artinya nilai tersebut $<0,7$ atau dapat dikatakan petani yang memiliki luas lahan 1-2ha dikatakan belum efisien secara teknis. Nilai tersebut menunjukkan bahwa usahatani semangka mampu mencapai $65,5 \%$ dari produksi semangka potensial yang bisa dicapai. Sedangkan untuk petani semangka yang memiliki luas lahan $>2$ ha (luas) sebesar 4 petani dari sampel petani semangka dengan rata-rata efisiensi teknis sebesar 0,840 . Nilai tersebut menunjukkan bahwa usahatani semangka mampu mencapai $84,0 \%$ dari 
produksi semangka potensial yang bisa dicapai. Terdapat 4 petani dalam usahatani semangka yang efisien secara teknis menurut tingkatan luas lahan dikarenakan $\geq 0,7$.

Mayoritas petani yang memiliki lahan sempit untuk berusahatani semangka di Desa Mayangan yaitu status lahan yang dimiliki adalah miliksendiri. Petani yang menanam pada areal lahan sewa lebih efisien secara teknis dikarenakan petani mampu mengalokasikan penggunaan input produksi dibandingkan dengan lahan sendiri. Petani yang memiliki lahan sendiri lebih bebas dalam mengelolah usahataninya, bebas untuk merencanakan dan menentukan cabang usaha, serta bebas dalam menggunakan teknik dan cara budidaya yang paling dikuasai (Shinta, 2011).

Faktor-Faktor yang Mempengaruhi Inefisiensi Teknis Penggunaan Faktor-Faktor Produksi

\section{Usahatani Semangka di Desa Mayangan Kecamatan Gumukmas}

Suatu usahatani dapat dikatakan efisien secara teknis jika memiliki nilai sebesar 1. Hasil analisis menunjukkan dari usahatani semangka untuk efisiensi teknis kurang 1 atau sebesar 0,68. Hal ini dapat terjadi karena dalam suatu usahatani semangka di Desa Mayangan dapat dipengaruhi oleh faktor inefisiensi teknis. Tingkat inefisiensi teknis usahatani semangka di Desa Mayangan Kecamatan Gumukmas dipengaruhi faktor-faktor seperti umur petani (tahun), pengalaman (tahun), jumlah anggota keluarga (orang), pendidikan (tahun), dummy keikutsertaan kelompok, dan dummy kepemilikan lahan. Model mengenai tingkat inefisiensi teknis dapat dianalisis secara simultan dalam model Stochastic Production Frontier.

Tabel 6. Parameter Dugaan Faktor-faktor yang Mempengaruhi Inefisiensi Teknis Usahatani Semangka di Desa Mayangan

\begin{tabular}{llll}
\hline \multicolumn{1}{c}{ Variabel } & Koefisien & Stand-Error & t-hitung \\
\hline Konstanta & 1,271 & 0,412 & $3,083^{*}$ \\
Umur petani & $-0,003$ & 0,004 & $-0,588$ \\
Pengalaman & $-0,032$ & 0,014 & $-2,362^{*}$ \\
JAK & $-0,083$ & 0,058 & $-1,423$ \\
Pendidikan & $-0,012$ & 0,019 & $-0,631$ \\
Dummy keikutsertaan kelompok & $-0,446$ & 0,173 & $-2,578^{*}$ \\
Dummy kepemilikan lahan & 0,065 & 0,115 & 0,561 \\
\hline Sigma Squared & 0,070 & 0,023 & 3,017 \\
Gamma & 0,960 & 0,054 & 17,855 \\
Log-likelihood ratio & & & 8,731 \\
LR- test of the one sided error & & & 28,508 \\
\hline t-tabel & & & 2,016 \\
\hline LR-tabel & & & 14,853 \\
\hline
\end{tabular}

Sumber: Olahan Data Primer (2017)

Keterangan: * berpengaruh nyata pada taraf kesalahan 5\%

Nilai gamma sebesar 0,960, menunjukkan bahwa sebesar $96,0 \%$ dari error yang ada dalam fungsi produksi disebabkan oleh adanya inefisiensi teknis sedangkan sisanya $4,0 \%$ disebabkan oleh variabel kesalahan acak. Variabel-variabel yang berpengaruh terhadap inefisiensi teknis adalah pengalaman petani dan dummy keikutsertaan kelompok, sedangkan umur petani, jumlah anggota keluarga, pendidikan, dan dummy kepemilikan lahan tidak berpengaruh terhadap inefisiensi teknis. Variabel yang mempengaruhi inefisiensi teknis berdasarkan pendugaan parameter dengam metode MLE dapat dituliskan sebagai berikut:

\section{$\mathrm{TE}=1,271-0,003 Z 1-0,032 Z 2-0,083 Z 3-$ $0,012 \mathrm{Z} 4-0,446 \mathrm{DKK}+0,065 \mathrm{DKL}$}

Hasil perhitungan menunjukkan bahwa nilai konstanta dalam model yang mempengaruhi faktor inefisiensi teknis sebesar 1,271 dengan nilai t-hitung adalah 3,803 atau lebih besar dari t-tabel $(2,016)$. Artinya jika tidak terjadi perubahan pada variabel umur petani, pengalaman, jumlah anggota keluarga, pendidikan, dummy keikutsertaan kelompok tani, dan dummy kepemilikan lahan maka nilai inefisiensi teknis usahatani semangka di Desa Mayangan adalah 1,271 .

Berikut penjelasan setiap masing-masing variabel yang mempengaruhi faktor-faktor inefisiensi teknis dalam usahatani semangka di Desa Mayangan Kecamatan Gumukmas Kabupaten Jember antara lain: 


\section{a. Umur petani ( $Z_{1}$ dalam tahun)}

Hasil pengujian secara individual (t-hitung) sebesar $0,588<$ t-tabel 2,016. Nilai tersebut menunjukkan bahwa variabel umur petani tidak berpengaruh nyata terhadap inefisiensi teknis dalam usahatani semangka. Nilai koefisien $-0,003$ menunjukkan pengaruh negatif terhadap inefisiensi teknis. Tanda negatif artinya jika terjadi penambahan satu tahun variabel umur petani akan menurunkan inefisiensi teknis sebesar 0,003 . Hal ini tidak sesuai dengan dugaan awal bahwa semakin bertambah umur petani, maka efisiensi teknis akan semakin menurun. Variabel umur tidak selalu menurunkan efisiensi teknis atau meningkatkan tingkat inefisiensi teknis.

Menurut Suratiyah (2015), semakin tua umur petani maka semakin berpengalaman petani dan akan semakin baik dalam mengelola usahataninya. Petani semangka di Desa Mayangan dalam melakukan usahatani semangka mayoritas $>5$ tahun. Keberhasilan usahatani semangka di Desa Mayangan dapat ditentukan oleh lama pengalaman petani dalam melakukan usahatani semangka.

\section{b. Pengalaman petani $\left(Z_{2}\right.$ dalam tahun)}

Hasil pengujian secara individual (t-hitung) sebesar 2,362>t-tabel 2,016. Nilai tersebut menunjukkan bahwa variabel pengalaman petani berpengaruh nyata terhadap inefisiensi teknis. Nilai koefisien - $-0,032$ menunjukkan tanda negatif artinya jika terjadi penambahan satu tahun variabel pengalaman akan menurunkan inefisiensi teknis sebesar 0,032. Hal ini menunjukkan bahwa semakin lama pengalaman petani dalam usahatani semangka maka akan semakin efisien secara teknis atau tingkat inefisiensi teknis semakin menurun.

Berdasarkan hasil wawancara dari 50 petani semangka terdapat 28 orang petani yang melakukan usahatani dari 5-10 tahun dan 11 orang petani yang melakukan usahatani semangka $>10$ tahun. Usahatani semangka di Desa Mayangan dilakukan sejak tahun 1990-an. Hal ini menunjukkan bahwa usahatani semangka sudah lama dijalankan. Semakin banyak pengalaman yang didapat petani dalam berusahatani maka petani semakin banyak belajar dari usahatani sebelumnya untuk digunakan pembelajaran pada usahatani berikutnya. Mayoritas petani yang melakukan usahatani semangka adalah mata pencaharian utama masyarakat Desa Mayangan.

Menurut Lubis (2014), semakin lama petani dalam melakukan budidaya maka semakin mengetahui petani baik dan buruknya usahatani yang dilakukan serta lebih memahami cara pemakaian input yang optimal. Hal tersebut diduga dapat meningkatkan efisiensi teknis atau dapat menurunkan inefisiensi teknis. Sedangkan, menurut Amarasuriya et al. (2007) semakin lama seorang petani dalam berbudidaya semangka maka petani semakin terampil dalam usahataninya dan akan berdampak positif terhadap efisiensi teknis dan berdampak negatif terhadap inefisiensi teknis.

\section{c. Jumlah anggota keluarga ( $Z_{3}$ dalam orang)}

Hasil pengujian secara individual (t-hitung) sebesar $1,423<$ t-tabel 2,016. Nilai tersebut menunjukkan bahwa variabel jumlah anggota keluarga tidak berpengaruh nyata terhadap inefisiensi teknis dalam usahatani semangka. Nilai koefisien 0,083 menunjukkan pengaruh negatif terhadap inefisiensi teknis. Artinya jika terjadi penambahan satu orang jumlah anggota keluarga akan menurunkan inefisiensi teknis sebesar 0,083 .

Hasil penelitian di lapang menunjukkan bahwa semakin banyak jumlah anggota keluarga maka dapat menurunkan inefisiensi teknis. Variabel jumlah anggota keluarga dianggap dapat menurunkan inefisiensi teknis karena semakin banyak jumlah anggota keluarga maka semakin banyak yang dapat membantu petani dalam usahatani semangka. Hal tersebut menunjukkan bahwa petani semangka akan mudah dalam mendapatkan tenaga kerja. Tetapi, variabel jumlah anggota keluarga tidak berpengaruh nyata terhadap inefisiensi teknis dikarenakan jumlah anggota keluarga petani dalam penelitian mayoritas adalah 3-4 orang dengan persentase $64 \%$. Jumlah anggota keluarga tersebut hanya terdiri ayah, ibu, dan anak sehingga yang berperan dalam usahatani semangka hanya sedikit.

\section{d. Pendidikan ( $Z_{4}$ dalam tahun)}

Hasil pengujian secara individual (t-hitung) sebesar $0,631<\mathrm{t}$-tabel 2,016. Nilai tersebut menunjukkan bahwa variabel pendidikan tidak berpengaruh nyata terhadap inefisiensi teknis. Nilai koefisien $-0,012$ menunjukkan nilai negatif terhadap inefisiensi teknis. Artinya jika terjadi penambahan satu tahun pendidikan akan menurunkan inefisiensi teknis sebesar 0,012. Hal ini menunjukkan bahwa semakin lama tingkat pendidikan petani semangka maka akan menurunkan tingkat inefisiensi. Menurut Sari (2013), bahwa variabel umur petani berpengaruh negatif dan signifikan terhadap inefisiensi teknis. Semakin tinggi pendidikan petani akan membuat petani memiliki pola pikir yang lebih baik dan mampu menerima teknologi baru serta dengan mudah dapat menyerap informasi.

\section{e. Dummy keikutsertaan kelompok tani}

Hasil pengujian secara individual (t-hitung) sebesar 2,578> t-tabel 2,016. Nilai tersebut menunjukkan bahwa variabel dummy keikutsertaan kelompok tani berpengaruh nyata terhadap inefisiensi teknis dalam usahatani semangka. Varibel dummy keikutsertaan kelompok tani menggunakan skala 
pengukuran jenis nominal berbeda dengan variabel inefisiensi lainnya yang mengunakan skala rasio. Hal ini dikarenakan variabel keikutsertaan kelompok tani memiliki dua jenis yaitu petani yang mengikuti kelompok tani dan petani yang tidak bergabung dalam kelompok tani. Menurut Lubis (2014), dummy kelompok tani berpengaruh negatif dan signifikan terhadap inefisiensi teknis atau dapat meningkatkan efisiensi teknis. Hal ini menunjukkan bahwa dalam kelompok tani akan terjalin kerjasama serta berbagi informasi dan pengetahuan tentang budidaya usahatani yang dilakukan. Petani yang bergabung dalam kelompok tani akan mendapatkan keuntungan berupa akses informasi dan wawasan yang dapat menurunkan inefisiensi teknisnya.

Keikutsertaan kelompok tani diukur dengan dummy, dimana petani semangka yang menjadi anggota kelompok tani diberi nilai 1 dan petani bukan anggota kelompok tani diberi nilai 0 . Nilai koefisien $-0,448$ menunjukkan apabila petani tidak bergabung dalam kelompok tani maka inefisiensi teknis yang diperoleh lebih tinggi 0,448 dibandingkan dengan petani yang bergabung pada kelompok tani. Hal ini menunjukkan bahwa kondisi daerah penelitian, peran kelompok tani yang ada tidak berjalan sebagai semestinya. Kelompok tani yang terdapat di daerah penelitian hanya berperani dalam menampung bantuan seperti pupuk dan mengadakan pelatihan. Petani yang bergabung dalam kelompok tani cenderung bekerja sendiri-sendiri dan kurang ada koordinasi terkait aspek teknis atau budidaya di lapang. Sehigga petani yang tidak bergabung dalam kelompok tani lebih menurunkan tingkat inefisiensi teknis atau meningkatkan efisiensi teknis dibandingkan petani yang bergabung dalam kelompok tani.

\section{f. Dummy kepemilikan lahan}

Hasil pengujian secara individual (t-hitung) sebesar $0,561<$ t-tabel 2,016. Nilai tersebut menunjukkan bahwa variabel tidak berpengaruh nyata terhadap inefisiensi teknis dalam usahatani semangka. Variabel kepemilikan lahan menggunakan skala pengukuran jenis nominal berbeda dengan variabel inefisiensi lainnya yang mengunakan skala rasio. Hal ini dikarenakan variabel kepemilikan lahan memiliki dua jenis yaitu petani yang memiliki lahan dengan sistem milik sendiri dan sewa. Petani yang menanam pada areal lahan sewa lebih efisien secara teknis dikarenakan petani mampu meminimalkan penggunaan input produksi dibandingkan dengan lahan sendiri.

Kepemilikan lahan petani diukur dengan dummy, dimana petani semangka yang mempunyai lahan milik sendiri diberi nilai 1 dan petani yang memiliki lahan sewa diberi nilai 0 . Nilai koefisien 0,065 menunjukkan apabila petani memiliki lahan sendiri maka inefisiensi teknis yang diperoleh lebih tinggi 0,065 dibandingkan dengan petani yang memiliki lahan sewa. Hal ini petani yang memiliki lahan sendiri bebas menentukan faktor produksi yang digunakan sesuai dengan pengalamannya tanpa dipengaruhi oleh orang lain. Berbeda dengan petani yang sistemnya menyewa lahan sehingga mereka berusaha menggunakan input produksi yang tersedia secara efisien.

\section{KESIMPULAN}

1. Faktor-faktor yang mempengaruhi produksi semangka di Desa Mayangan adalah luas lahan (ha), tenaga kerja (HOK), pupuk organik ( $\mathrm{kg}$ ), pupuk kimia (kg), bibit (buah), pestisida cair ( $\mathrm{mL}$ ), dan pestisida padat $(\mathrm{kg})$. Hasil estimasi dari parameter Maximum Likelihood Estimates (MLE) untuk fungsi produksi Stochastic Frontier CobbDouglas menunjukkan bahwa variabel luas lahan, tenaga kerja, pupuk organik, pupuk kimia, dan bibit berpengaruh nyata terhadap produksi semangka. Sedangkan variabel pestisida cair dan pestisida padat tidak berpengaruh nyata terhadap produksi semangka di Desa Mayangan Kecamatan Gumukmas.

2. Tingkat efisiensi teknis petani semangka di Desa Mayangan Kecamatan Gumukmas dalam penggunaan faktor-faktor produksi semangka masih belum efisien secara teknis dikarenakan nilai rata-rata efisiensi teknis 0,68 (inefisiensi teknis) $<0,7$. Petani yang memiliki nilai efisiensi teknis $\geq 0,7$ dan tergolong petani yang telah efisien secara teknis berjumlah 20 orang atau $40 \%$ dari petani sampel. Sedangkan petani yang memiliki nilai efisien teknis $<0,7$ dan tergolong belum efisien secara teknis berjumlah 30 orang atau $60 \%$ dari petani sampel.

3. Faktor-faktor yang mempengaruhi inefisiensi teknis secara parsial dalam usahatani semangka di Desa Mayangan adalah pengalaman petani (tahun) dan dummy keikutsertaan kelompok tani. Variabel pengalaman dan dummy keikusertaan kelompok tani berpengaruh negatif dan nyata terhadap dengan koefisiensi 0,032 dan 0,448 . Sedangkan variabel umur, Jumlah anggota keluarga, pendidikan dan dummy kepemilikan lahan tidak berpengaruh nyata terhadap inefisiensi teknis. 


\section{SARAN}

Berdasarkan hasil penelitian, maka beberapa saran yang dapat diberikan untuk peningkatan produksi dan efisiensi teknis usahatani semangka di Desa Mayangan Kecamatan Gumukmas Kabupaten Jember adalah sebagai berikut:

1. Sebaiknya petani dalam melakukan usahatani semangka di Desa Mayangan perlu memperhatikan penggunaan input. Seperti contoh, penggunaan pupuk kimia yang sesuai dengan anjuran akan dapat meningkatkan produksi. Sehingga akan meningkatkan efisiensi penggunaan pupuk kimia dalam usahatani semangka di Desa Mayangan Kecamatan Gumukmas.

2. Perlu digiatkan petani yang belum bergabung dalam kelompok tani agar memiliki akses yang lebih baik terkait informasi teknologi terutama cara budidaya semangka sehingga dapat meningkatkan efisiensi teknis. Sedangkan petani yang bergabung lebih meningkatkan koordinasi antara anggota agar mampu menginformasikan aspek teknis dan budidaya mengenai semangka.

\section{DAFTAR PUSTAKA}

Amarasuriya MT, Edirisinghe J, Patalee MA. 2007. Tehnical Efficiency in Introcropped Pineapple Production in Kurunegala District. Paper. Departement of Agribusiness Management. Wayamba University of Sri Lanka.

Apriani, Leni Nurul 2011. Analisis Efisiensi Teknis dan Pendapatan Usahatani Bawang Merah (Studi Kasus: desa Sukasari KAler, Kecamatan Argapura, Kabupaten Majalengka, Provinsi Jawa Barat). Skripsi. Departemen Agribisnis Fakultas Ekonomi dan Manajemen Institut Pertanian Bogor: Institut Pertanian Bogor

Arikunto, Suharsimi. 2013. Prosedur Penelitian Suatu Pendekatan Praktik. Jakarta: PT. Rineka Cipta.

Badan Statistik Konsumsi Pangan. 2015. Statistika Konsumsi Pangan Tahun 2015. Jakarta: Kementerian Pertanian.
Coelli TJ, DSP Rao, GE Battese. 1998. An Introduction to Efficiency and Productivity Analysis. Kluwer Academic Publishers, London.

Kalie, Moeh Baga. 2002. Bertanam Semangka. Jakarta: Penebar Swadaya.

Laksmayani, Made Krisma., Alimudin Laapo, dan Sulaeman. 2013. Analisis Efisiensi Penggunaa Input Produksi Usahatani Semangka di Desa Maranatha Kecamatan Sigi Biromaru Kabupaten Sigi. Agrotekbis. Vol 1 (2): 185-191.

Lubis, Riatania Rizal Basjrah. 2014. Analisis Efisiensi Teknis, Alokatif Dan Ekonomi Produksi Nanas Di Kabupaten Subang Provinsi Jawa Barat. Tesis. Sekolah Pascasarjana Institut Pertanian Bogor: Institut Pertanian Bogor

Nazir, Mohammad. 2003. Metode Penelitian. Jakarta: Ghalia Indonesia.

Ni'am, Aula. 2014. Analasis Fungsi dan Skala Produksi Usahatani Buah Semangka Non-biji di Lahan Pasir Desa Mojosari Kecamatan Puger. Skripsi. Fakultas Pertanian Universitas Jember.

Prajnanta, Final. 2001. Agribisnis Semangka NonBiji. Depok. Penebar Swadaya.

Putri, Galih Citra Loana. 2010. Analisis Efisiensi Ekonomi Penggunaan Faktor-faktor Produksi pada Usahatani Semangka (Citrullus vulgaris) di Kabupaten Purworejo. Skripsi. Universitas Sebelas Maret Surakarta.

Sari, Diki More. 2013. Analisis Efisiensi Teknis dan Pendapatan Usahatani Baby Buncis pada Petani Mitra International Cooperation And Development Fund (ICDF) Bogor. Skripsi. Bogor: Departemen Agribisnis, Fakultas Ekonomi dan Manajemen, Institut Pertanian Bogor.

Shinta, Agustina. 2011. Ilmu Usahatani. Malang: UB Press.

Sugiyono. 2014. Metode Penelitian Kuantitatif KualitatifDan $R \& D$. Bandung: Alfabeta.

Suratiyah, Ken. 2015. Ilmu Usahatani. Jakarta Timur: Penebar Swadaya. 